\title{
Ever since Hightower: The politics of agricultural research activism in the molecular age ${ }^{1}$
}

\author{
Frederick H. Buttel \\ Department of Rural Sociology and Institute for Environmental Studies, University of Wisconsin, Madison, Wisconsin, USA
}

Accepted in revised form June 24, 2005

\begin{abstract}
In 1973, Jim Hightower and his associates at the Agribusiness Accountability Project dropped a bombshell Hard Tomatoes, Hard Times - on the land-grant college and agricultural science establishments. From the early 1970s until roughly 1990, Hightower-style criticism of and activism toward the public agricultural research system focused on a set of closely interrelated themes: the tendencies for the publicly supported research enterprise to be an unwarranted taxpayer subsidy of agribusiness, for agricultural research and extension to favor large farmers and be disadvantageous for family farmers, for public research to stress mechanization while ignoring the concerns and interests of farm workers, and for the research and extension establishment to ignore rural poverty and other rural social problems. By 1990, however, there had been a quite fundamental restructuring of the agricultural technology opposition movement - one that is not often well recognized. Two overarching changes had occurred. First, agricultural-technology activism had shifted from contesting land-grant/public research priorities and practices to contesting private agribusiness technological priorities and practices. Second, the relatively integrated, overarching Hightower-type opposition had undergone bifurcation into two quite distinct social movements: the agricultural sustainability/local food systems movement on one hand, and the anti-GM food/crop and anti-foodsystem-globalization movement on the other. In this paper I explore the causes and consequences of these restructurings of the agricultural research and technology opposition movement. Chief among the major factors involved was the fact that "Hightowerism" involved an ineffectual representational politics. Hightowerist claims especially the claim that land-grant research was detrimental to family farmers - generated little support among the groups it claimed to represent (particularly "small" or "family" farmers). The two successor movements, by contrast, have relatively clear and dependable constituents. Further, the progressive molecularization of agricultural research, which proved to be both an antecedent and consequence of corporate involvement in agricultural research in the US, has decisively changed the issues that are contested by technology activists. Since the age of Hightower, the agricultural technology activist movement has shifted its 1970s and early 1980s emphasis from contesting public sector/land-grant research priorities to contesting private sector activities, particularly genetic engineering, GM crops, and globalization of agricultural technologies and regulatory practices. Even the sustainability/localism wing of the new agricultural technology movement configuration has progressively backed away from contesting public research priorities. The efforts of the sustainable agricultural and localism movement have increasingly focused on quasi-private efforts such as community supported agriculture, green/“value-added" labeling and marketing strategies, and community food security. Some implications of this increasingly bifurcated, agricultural technology, activist movement configuration in which there is decreased interest in land-grant/public research priorities are discussed.
\end{abstract}

Key words: Activism, Agricultural science and technology, Jim Hightower, Land-grant universities, Productivist ideology, Public agricultural research

Frederick H. Buttel was Professor and past Chair, Department of Rural Sociology, Professor of Environmental Studies, and Associate Director of the Program on Agricultural Technology Studies, University of Wisconsin, Madison. In addition to having served as President of the Agriculture, Food, and Human Values Society (19981999), he was President of the Rural Sociological Society (1990-1991) and the recipient of their Distinguished. Rural Sociologist Award (2004). In 2004, he received the University of Wisconsin's highest honor and was named The William H. Sewell Professor of Rural Sociology. 


\section{Introduction}

It is widely recognized that during the brief span from roughly the mid-1960s to the early 1980 s there was a sea change in the politics of public - and, for that matter, private - agricultural research. Shortly after the battles over the structure of public sector research had been settled in the $1930 \mathrm{~s},{ }^{2}$ and following on the hybrid corn success story of the 1930s and 1940s, the American public agricultural research system entered a stable pattern of very rapid growth and growing public legitimacy. The legitimacy of domestic, public agricultural research was cemented even further by the enormous flood of favorable publicity in the late 1960s about the green revolution, especially in India. The apogee of the American public agricultural research system can be marked by the awarding of the Nobel Peace Prize in 1970 to Norman Borlaug, the well-known CIMMYT wheat breeder and the global public face of the green revolution.

The essence of this Golden Age of American public agricultural research was not simply its favorable public image. The golden age had a very definite social structure, which was largely an outcome of the late nineteenth century struggle over public research. The US was a late-comer to public agricultural research, one of the major reasons for which was widespread farmer ambivalence about research (Danbom, 1979, 1986). Public research was well developed in Germany and England by the 1860s and 1870s (Ruttan, 1980), but there was virtually no public agricultural science (as commonly understood, as a form of knowledge production distinct from farmer knowledge production) in the US until the late $1890 \mathrm{~s}$, and even then the US agricultural research system was far weaker than its counterparts in Germany and England. The structure of the land-grant system was a compromise among the various groups advocating and resisting various designs for a public agricultural research system (Marcus, 1986). While the key institutional framework for the land-grant system was provided by the Morrill Act of 1862 (which established the land-grant agricultural and mechanical colleges), it was the Hatch Act of 1887 (which established land-grant experiment stations on land-grant college campuses) that began to cast the institutional die for the land-grant system as a research enterprise.

The outcomes of these struggles, which were reflected most concretely in the provisions of the Hatch Act of 1887, involved several distinctive components. ${ }^{3}$ There was an emphasis on applied, locally adapted research (research that would be immediately useful and which was consistent with the wide range of local agroecological conditions in the country). The public research system was mainly state-funded. A predominance of state funding overcame farmer opposition to federally funded, productivity-increasing research; the land-grant ratio- nale ${ }^{4}$ was to support research in one's state to enable farmers in that state (e.g., Wisconsin) to compete with farmers in other states (e.g., Michigan and Minnesota). With the passage of the Smith-Lever Act of 1914, Cooperative Extension became an integral part of the land-grant model. Extension's publicly funded technology transfer system was consistent with the "management" (or noncommodity) emphasis of much early agricultural technology. Also integral to the land-grant model was the predominance of public domain (nonpatented) knowledge, which contributed to both research and relatively rapid transfer through extension. Finally, the land-grant system was not only reasonably effective in its own right in terms of bringing science to bear on agricultural improvement, but its rise occurred in tandem with the expansion of public higher education. The American public agricultural research system thus went from being miniscule in 1900 to being widely regarded as the world's largest and most accomplished by the end of the $1950 \mathrm{~s}$ - a remarkable feat made possible by the expansion of strong public funding support for public research that the decentralized, state-funded land-grant system made possible. The impressive accumulation of new technological advances that occurred as a result of mid-century land-grant research led to the consolidation of a technologically attentive class of early-adopting farmers and to the establishment of federal agricultural commodity policies to deal with surpluses (Goodman and Redclift, 1991). This period, which lasted until roughly the early 1970s, has been referred to by the historian of the College of Agriculture at my university as the "golden age" of the land-grant system (Jenkins, 1991: 134).

Two additional components of the golden age of US public research are germane to the topic of this paper. First, the land-grant/experiment station compromise that overcame farmer ambivalence about federally sponsored agricultural research reflected a largely invisible, but powerful coalition in support of public research. This coalition was a "productivist coalition," which is to say that there was agreement among the elites of several key institutions - farm commodity groups, land-grant administrators, agribusiness firms, and federal agricultural agencies - that the underlying goal of research was to increase agricultural productivity, to enable progressive farmers to modernize their way out of their problems (as opposed to seeing populism and socialism as attractive alternatives). Note that while the rank-and-file of farmers was not part of this coalition, integral to the discourses on behalf of productivism was the notion that the ordinary farmer was its chief beneficiary. Productivism was not only the largely unstated goal of research but also a pervasive ideological posture. The essence of the predominant "productionist" ideology was a doctrine that increased production is intrinsically socially 
desirable, and that all parties benefit from increased output. Productionism emphasized the collective benefits of new technology and implicitly concealed the social costs of technological change and the unequal ways in which the benefits of new technology are distributed. Productionist ideology was particularly efficacious in providing a shared sense of purpose among the public agricultural research community, agroindustry (including not only agro-input and agro-output firms but also banks), major farm organizations (especially commodity organizations), and federal agricultural policy makers. Productionism was typically promulgated through a characteristic "magic bullet" symbolization - of charts of data showing increased yields and output, and the declining share of consumer paychecks going to food expenditures on one hand, juxtaposed with particular "big-hit" technologies (e.g., hybrid corn, green revolution rice and wheat varieties, DDT, artificial insemination) on the other. Productionist ideology also reflected a high comfort level with private sector commercialization of public research results (Buttel, 1993). During the golden age there was corresponding growth in the role of private $R \& D$; the private share of agricultural $R \& D$ increased from about $1 / 3$ in 1940 s to $2 / 3$ by 1980 , culminating in a substantially decreased public sector role in shaping new technology.

The hegemony of productivist ideology corresponded with a very positive public perception of agricultural scientists and scientific institutions as being selfless heroes who labored in support of the mission to feed the hungry and bring about ever-increasing food security. The heroic imagery of public agricultural science (Ruttan, 1980: 110) was buttressed in particular by the late 1960s and early 1970s successes associated with the green revolution in the global South. As noted earlier, this imagery culminated in the awarding of the 1970 Nobel Peace Prize to Norman Borlaug, the acclaimed CIMMYT wheat breeder whose research on short-statured wheat varieties led to rapid increases in that production in South Asia.

\section{The rise and fall of Hightowerism}

It is startling to understand in historical retrospect how quickly the imagery of heroism and the unchallenged authority of public agricultural science went into decline in the 1970s. There are a good many reasons for this decline. Beginning with the Pound Report of 1972 (National Academy of Sciences, 1972), there emerged a growing tide of basic science criticism of public research - that public research was too applied, too commodity oriented, too routine, and not oriented enough to basic biology. The basic science critics of traditional, applied, formula ("Hatch")-funded agricultural research were not numerous; rather, they tended to be the most prominent scientists at the most prominent colleges of agriculture. These sentiments were reflected in the Pound Report - a kind of land-grant "friendly fire" - which challenged the applied research pillar of the land-grant golden age model by arguing that the emphasis on applied research had led to scientific complacency and inefficiency.

The 1970s and 1980s also ushered in a number of trends that undermined the stability of other components of the golden age model. During the mid-1970s there first emerged public fiscal austerity and stagnation of federal agricultural research funding - particularly with respect to public support for applied research through formula funding. The Cohen-Boyer rDNA discovery in 1972 buttressed the position of basic science critics of public research and led to a growing consensus among landgrant administrators and federal research policy makers that applied, locally adapted, commodity-driven conventional research was becoming obsolete.

But as or more fundamental than all of the preceding structural changes that began to undermine the golden age model of public research was the rise of social opposition to agricultural research and technology, including but not limited to public agricultural research. Opposition to public research began with criticism of the "green revolution" in the late 1960 s, very shortly before Borlaug won the Nobel Peace Prize (on the early history of this opposition, see Cleaver, 1972; Dahlberg, 1979; see especially Perkins, 1997, for the history of the wheat green revolution and its opponents). While the anti-green revolution movement has evolved considerably since that time, it has remained vibrant to this day, and has contributed to the international agricultural research centers (now known as "future harvest centers") of the CGIAR being continually on the defensive.

By "Hightowerism," I refer to the movement associated with Jim Hightower's book, Hard Tomatoes, Hard Times (1973) and with the organization, the Agribusiness Accountability Project, he helped to found in the late 1960s. Hightower's Hard Tomatoes, Hard Times was a devastating bombshell heaved at the land-grant and agricultural science communities. Not only did Hightower's arguments directly attack some of the major presumptions underlying productivist policy and ideology, but Hightower's tone was often cynical and mocking, rubbing salt in the newly opened wounds. While some land-grant deans dealt with Hightower's criticisms largely by ignoring them, others, such as Ohio State University's agriculture dean, Roy M. Kottman, felt compelled to repeatedly address Hightower's book and criticize his arguments in his speeches to constituents and fellow land-grant administrators. Hard Tomatoes, Hard Times induced a number of like-minded people to form new movement organizations or to include anti-land-grant agendas within existing organizations. Related social 
movement organizations/NGOs during the 1970s included the Center for Rural Affairs (CRA), Rural America, and, to a lesser extent, the Conference on Alternative State and Local Policies and the Exploratory Project for Economic Alternatives. State-level groups such as the Wisconsin Rural Development Center emerged during the 1970s and early 1980s in the Hightowerist mold. The venerable Institute for Policy Studies (IPS), which had previously focused almost entirely on urban and industrial issues, developed a program on rural America that reflected the major themes of the Hightower book (see Belden, 1986, which was published under IPS auspices). Of these groups, only the CRA and IPS still exist today.

In many respects what I call "Hightowerism" was an extension of the anti-green revolution movement to the US context. The anti-green revolution and Hightowerist movements were anchored in very similar claims and discourses - that the new technologies developed by public researchers tended to benefit large farmers/peasants over small farmers/peasants and provided particular benefit to agribusiness. During the heyday of Hightowerism, from roughly the late 1970 s to the early 1980 s, a related claim - that public land-grant agricultural research prejudiced the integrity of the rural natural environment - was added to the original social-justice-type emphasis of Hightowerism. ${ }^{5}$ Both movements involved a key role played by NGOs that were staffed primarily by a nonfarmer intelligentsia and supported primarily by funds from progressive foundations. Both were left-wing movements mistrustful of both corporate agribusiness and state officials who supported agribusiness domination of research and agricultural development. Both movements, however, aimed in substantial measure to represent the interests of small farmers/peasants and to encourage the mobilization of farmers to oppose prevailing agricultural research priorities.

Through the 1970s and early 1980s, Hightowerism was the prevailing social movement type with respect to agricultural science and the land-grant system (see Hadwiger and Browne, 1978; Hadwiger, 1982). ${ }^{6}$ Belden's Dirt Rich, Dirt Poor (1986) - a book title that was no doubt intended to demonstrate its lineage with Hightower's Hard Tomatoes, Hard Times - was arguably the last hurrah of Hightowerism. Belden's book was published during the height of the mid-1980s farm crisis. One might imagine that the farm crisis would have helped to bolster the Hightowerist movement. The farm crisis seemed to demonstrate that decades of focus on increased productivity had led to chronic overproduction and to an unhealthy dependence on the agricultural export market rather than to widespread benefits to American farmers. But, in fact, Hightowerism had essentially disappeared by the time the farm crisis had run its course in the late 1980s. ${ }^{7}$
Why is it, then, that Hightowerism was beginning to disappear by approximately 1987 or 1988 when the antigreen revolution movement was still vibrant, and when the 1980s farm crisis seemingly made the contradictions of productivity-increasing agricultural research all the more obvious (Goodman and Redclift, 1991)? There were arguably four major contradictions of Hightowerism. First, the key agenda item of Hightowerism - that public agricultural research must be restructured to permit the development of new technologies that benefit small or family farmers over larger farmers and agribusinesses - proved to be elusive, if for no reason other than the fact that a national public policy environment that favors capital-intensive, monocultural, chemicalintensive agriculture makes it enormously difficult to develop mere technological alternatives that help small farmers out-compete larger ones. Second, the farm crisis reinforced one of the central realities of agricultural research politics - that for most farmers research policy is relatively unimportant, in the sense that at any given time it almost always takes a back seat to farm price issues (Kloppenburg and Buttel, 1987). Third, there was virtually no mobilization of small or family farmers around a progressive Hightowerist agenda. This was partly due to the fact that research policy is not an immediate preoccupation on the part of most farmers. In addition, it proved to be the case that small and family farmers as petty property holders have been attracted more to conservative Republican views than to those of Hightower and Belden. Fourth, legislators and the leaders of USDA, state departments of agriculture, and both major political parties were strongly tied to large-scale, commercial agriculture and agroindustry and had no interest in supporting the Hightower agenda. Thus, the political economy of public research made it enormously difficult for a social movement to succeed in supplanting a research agenda that had long undergirded commercial agriculture and had so effectively cemented the productivist coalition. Finally, the 1980s were a time of a breathtaking pace of "molecularization" of land-grant and agroindustry research. Molecularization, as I will note below, decisively altered the politics of agricultural research and served to render Hightowerism as a mere historical footnote.

\section{Molecularization of agricultural research and the transformation of agricultural research activism}

Don Hadwiger's (1982) The Politics of Agricultural Research, the analysis which presumed that Hightowerism was destined to be a longstanding coherent challenge to productivism, was ironically published at the very moment that the land-grant system and the agricultural science disciplines were in an incipient stage of "mole- 
cularization" (or "geneticization"). The 1972 CohenBoyer rDNA discovery and subsequent advances in molecular biology during the 1970 s led to molecularization/geneticization of agricultural biology in the 1980s and 1990s. Molecular biology and molecular genetics became the trendiest and most interesting area of agricultural research. In the 1980 s universities began to compete over how molecular (or "biotechnological") their faculties were and over access to prestigious federal grants (e.g., NSF, NIH) that supported molecular biology research. There was a consequent de-emphasis on applied research staffing (e.g., traditional plant breeders) and the increased tendency to hire molecular-oriented agronomists, animal scientists, horticulturalists, and so on in land-grant universities (Busch et al., 1991).

The Plant Variety Protection Act of 1970, the Diamond v. Chakrabarty Supreme Court decision in 1980, the ex parte Hibbard Patent and Trademark Office decision (which permitted genes and crop varieties to be patented under Section 101 of the Patent Act), and the ex parte Allen decision (which affirmed the Chakrabarty decision by ruling that the Patent Office may not deny living organisms patentability for lack of novelty) increased the attractiveness of commercial agricultural biotechnology. As a result, much of the nation's agricultural R\&D activity shifted to agricultural biotechnology start-up companies (e.g., Calgene, Mycogen, Advanced Genetic Sciences) and to the chemical-seed multinational corporations (MNCs) such as Monsanto, Bayer, Ciba-Geigy (later Novartis and now Syngenta), Dow, Pioneer (now part of DuPont), and DuPont. The preceding trends occurred during a period of deindustrialization and the decline of traditional "rustbelt" industries and of a rapidly growing fascination with "high-technologies." There was a corresponding rise of international competition in high-technology that led to an increase in federal funding of basic research.

In addition, the Bayh-Dole Act of 1980 enabled universities to patent technologies developed with public funding. Bayh-Dole, and the lure of university patent revenue from molecular biology research, reinforced the molecularization of agricultural science. Bayh-Dole led to the rapid privatization of technology transfer, in which universities began to stress technology transfer that yields royalty income over gratis technology transfer (through Cooperative Extension). The 1980s and 1990s were a time of enormous expansion of federal funding of molecular biology and basic biology. ${ }^{8}$

It is now the conventional wisdom that the molecularization of agricultural research has generated a set of issues and debates - particularly over the environmental and health implications of GM crop varieties, over the role that "biotechnology" can or will play in alleviating hunger and poverty in the South, and over the privatization of agricultural research - that have generated a new stream of agricultural research activism. It is notable, however, that the anti-biotechnology movement represents a substantial departure from Hightower-style activism. While the agenda of Hightower and colleagues was to "contest public research priorities," the anti-biotechnology movement has had little to say about public research per se and, instead, has emphasized "contesting corporate R\&D and government policies" for regulating genetically modified crops. ${ }^{9}$

But it is perhaps equally important that the molecularization of "public" research was key in shaping agricultural research activism in yet another way. I noted earlier the overlapping reasons why Hightowerist activism failed to endure. Yet another reason why Hightowerism failed to endure was that members of this "ex/al" coalition (Hadwiger's, 1982 terminology for what he saw as the new form of Hightowerism that was strongly environmental in orientation) increasingly realized that the molecularized public research system presented an increasingly formidable obstacle to successful activism because of the declining emphasis of the land-grant system on applied research. The essence of Hightowerism was the claim that land-grant research, which had heretofore tended to be applied and geared to rapid farmer adoption as products sold by chemical, machinery, and other agribusiness firms, tended to benefit large, nonfamily farmers over smaller, family-type operators. The molecularization trend, however, was leading landgrant research to be decreasingly applied. To the degree that "basic" or "fundamental" land-grant research was contributing to the demise of family farmers, local agribusiness, and rural communities, it did so only indirectly, by way of patented knowledge licensed to multinational firms.

As Hightower-type agricultural research activism lost its momentum, a good many movement adherents, as well as large numbers of additional supporters, came to be attracted to the localism/sustainable agriculture movement (or movements). The localism/agricultural sustainability movement arose in a limited way in the late 1970 s, largely in continuity with the organic farming movement and also as a reflection of the growing interest of mainstream environmental groups (such as the Sierra Club) in rural and agricultural environmental issues. The localism/sustainability "movement" - including the numerous small to large corporate enterprises associated with it - is vastly larger than the organic movement in the late 1890s and 1970s. Also note, that while Hightower and associates made some occasional mention of the environmental consequences of land-grant research priorities, Hightowerism in its original form was mainly a "social" critique of agricultural technoscience. By 1980, however, Hightowerism, during its latter stages, had undergone pronounced "environmentalization" or "greening." Thus, in Hadwiger's (1982) portrayal of 
activist opposition to land-grant research, he finds that the environmental shortcomings of land-grant research are given as much play as concerns about the unequal social impacts of technology as motivations for and discourses in research activism.

Much like the anti-biotechnology movement, the key focus of the contemporary localism/sustainable agriculture movement is no longer on contesting and altering land-grant and public research priorities. As the 1980s and 1990s proceeded, sustainable agriculture became less a critique of public agricultural research, and more a critique of long-distance agrofood commodity chains and of the sociospatial separation of production and consumption. This is not to say that sustainable agriculture and food system localization advocates are pleased with the molecular orientation and patent-driven technology transfer emphasis of the land-grant system. Most sustainable agriculture and food system localization supporters condemn the land-grant system for the lack of sustainable agriculture research. Organic farmers and merchandisers have fiercely defended the position that 100 USDA certified organic foods must contain no genetically engineered content. In contrast to organic advocates in the 1980s, however, most organic movement participants do not see activism against the landgrant system to be a high priority use of their time.

The sustainable agriculture movement increasingly aimed to build an alternative locally based food system involving more direct linkages (such as direct marketing, farmers markets, community supported agriculture) between farmers and consumers. Other important segments of the sustainable agriculture activist community stress the development of green/"value-added" labeling and marketing strategies, while others stress issues such as community food security (Buttel, 1997; see the special issue on "The Restructuring of Food Systems" in Agriculture and Human Values 16(2), 1999 for a comprehensive set of papers on the private sector/civil society and community food security foci of the sustainable agriculture movement).

As suggested earlier, the foregoing argument is not meant to imply that either the anti-biotechnology movement or the localism/sustainable agriculture movement entirely neglect public agricultural research and the land-grant system or are pleased with what land-grant colleges of agriculture do. Much anti-biotechnology activism, to be sure, involves the conviction that landgrant university priorities and policies, such as the molecularization of their faculties, their coziness with biotechnology firms, and their quest to capture royalties from patented biological innovations have contributed to the momentum behind the development of risky GM crop varieties (Krimsky and Wrubel, 1996; Rissler and Mellon, 1996). Sustainable agriculture and food system localization activists also routinely lament the lack of attention to agroecology and sustainable agriculture in land-grant universities and the tendency for the landgrant system to be decreasingly responsive to the technical needs of farmer constituents. This said, contemporary agricultural research and technology activism is directed at land-grant universities to a much smaller degree than was the case during the 1970s and 1980s.

\section{Concluding remarks}

In 1988 I published a paper in Agricultural History (Buttel and Busch, 1988) in which I stated matter of factly that there was destined to be a permanent base of (Hightowerist) opposition to land-grant institutions and the agricultural sciences. In large part, this prediction has not stood the test of time. There is, to be sure, a set of contemporary social movements that actively contest agricultural technoscience and the social arrangements that this new technoscience has helped to shape. But the omnibus Hightower-type movement that seemed to have considerable momentum and vitality in the mid to late 1980s had by the mid-1990s or so become substantially bifurcated. Hightowerism yielded to the localism/sustainable agriculture movement and the anti-biotechnology movement. Both movements contest the technological (and the related social) roots of American agriculture. Neither movement does so, however, by placing its major emphasis on contesting land-grant research priorities and policies. The localism/sustainable agriculture movement has become something of a quasiprivate movement, striving to build an alternative food provisioning and marketing system within the private and civil society sectors, based on the principle that food system localization and closer producer-consumer relationships are the ideal. The anti-biotechnology movement most directly contests private agroindustry R\&D priorities and the regulatory policies of national governments and international regimes such as the World Trade Organization and Codex Alimentarius.

There are some contradictory implications of the decreasing focus of activist groups on land-grant priorities and policies. One possible implication is that the land-grant system has proven to be such a bureaucratic behemoth that activist groups have wound up giving up on the land-grant colleges of agriculture and experiment stations as basically being hopelessly impenetrable institutions. There is no doubt a kernel of truth to the proposition that the land-grant universities have shrugged off activist criticism and discouraged activist groups from engaging them. It should be noted, however, that much of the inertia within land-grant universities is fiscally driven. ${ }^{10}$ Activist groups have generally wanted to restructure land-grant colleges' "applied research priorities," but the predominant trend of the past 25 or so 
years has been the decreased availability of public funding for applied research, regardless of whether it is directed to the technical interests of large farmers and agribusinesses on the one hand, versus smaller or sustainable farmers on the other. ${ }^{11}$

Another possible implication is that these two movements largely eschew contestation of land-grant priorities because the land-grant system has become marginalized as a major actor in the modern agrofood system. Indeed, as noted earlier, the public research system no longer dominates agricultural R\&D as it did during the mid-century. Also, the land-grant system does a decreasing amount of applied research, so that the ensemble of technologies available to farmers is shaped less and less by the priorities of public researchers. Perhaps most importantly, as the land-grant system emphasizes more basic research, the impact of that research on farm structure, rural areas, and the food system is largely determined by what the land-grants' "agroindustrial partners" do when they appropriate the basic research findings of land-grant scientists.

A third implication is that land-grant administrators ought to have mixed feelings about the decline of public agricultural research activism. On one hand, in the short term, land-grant college deans would clearly prefer to have less rather than more scrutiny of their programs by citizen movements. On the other hand, the political lull they find themselves in involves a number of disquieting trends. Public interest, corporate and farmer groups do not find land-grant programs to be central enough to their agendas to place key stress on influencing land-grant priorities. The genetic engineering wars are going badly enough that land-grant administrators ought to be worrying about whether they have invested too much of their resources in molecular biology. Rampant budget cutting at the federal and state levels is wreaking progressively more havoc on the land-grants' applied research programs, and there seems to be no alternative but to watch over the almost complete demise of an effective landgrant applied research program. The continued erosion of formula (mostly "Hatch") funding, the weak position of the Initiative for Future Agriculture and Food Systems (IFAFS) grant program, and the fragile position of sustainable agriculture funding makes it the case that commodity groups are becoming the principal source of applied research funding. The growing role of commodity group funding, and the growing influence of groups that are known for their single-mindedness and pursuit of very narrow self-interests, is not very welcome - arguably even to many land-grant administrators. One might even make the argument that some of the signals that are coming to land-grant officials' offices suggest that the once-unimaginable - an initiative to regain the interest of nontraditional constituents and movement groups in the land-grant system - may have some attraction to them.
In the foregoing, I mentioned that while there are some discursive and ideological overlaps between the sustainable agriculture and anti-genetic engineering movements, they are largely separate movements that, most importantly, have quite different targets, discourses, and strategies. This said, there is one interesting operational commonality between the two. This concerns the fact that environmental organizations, such as the Sierra Club, Worldwatch Institute, and Friends of the Earth are active agents within both movements. Does this possibly or potentially portend a more comprehensive or amalgamated neo-Hightowerist movement in the years to come? My guess would be that there is little chance of this occurring. Not only do the two movements have quite different focal points and constituents, but there is the arguably more important matter that neither agriculture nor agricultural research and the land-grant system have ever been of great importance to American environmental movement leaders (Thompson, 2003: 212). Environmental movement involvement in these two agriculturally related issues (sustainable agriculture and genetic engineering) does not reflect a singular commitment to agricultural reform, but a more strategic and opportunistic appropriation of issue foci in ways that appeal to more metropolitan audiences. In sum, my anticipation is that Hightowerism as an omnibus movement aimed at altering land-grant agricultural research priorities in the interest of social justice with respect to a farmer clientele was a short-lived movement that has been replaced permanently by the sustainable agriculture and anti-genetic engineering movements.

\section{Notes}

1. Paper presented at the annual meeting of the American Sociological Association, Atlanta, Georgia, August 16, 2003.

2. The main structural components of the land-grant system were the predominance of state government (rather than federal funding), the emphasis on applied, locally adapted research, the general absence of proprietary protection of research knowledge, and the public technology transfer system (Cooperative Extension). The decentralized, statefunded system overcame the tendency for farmers to be ambivalent about research, since it was generally in the interest of farmers in a particular state for there to be a land-grant institution that developed new technology geared to the agroecological particularities of that state and its various regions.

3. Marcus (1986) has noted that to a substantial degree these compromises were worked out in the experience of establishing and operating the New York State Agricultural Experiment Station at Geneva, New York. The Geneva Station, which is now part of Cornell University's College of Agriculture and Life Sciences, was one of the experiment stations (including, most notably, the Connecticut 
Agricultural Experiment Station) that were established by state legislatures prior to the Hatch Act of 1887. The Geneva Station was established in 1879 and its operating practices were worked out during struggles lasting through the early $1880 \mathrm{~s}$. The main principles of operation were state funding of research to serve a mainly state farmer clientele, a balancing of "agricultural investigation" (essentially experimental research) and "agricultural practice" (essentially a practical bent to the formulation of problems along with a commitment to extend results to farmers in the state). The essence of the compromise was a focus on applied, locally adapted research of practical relevance to individual farmer profitability.

4. The old land-grant rationale - that which was reflected in the Morrill Act and also in farmer resistance to research in land-grant colleges during the 1870 s and 1880 s - was that land-grant colleges of agriculture should stress the teaching of modern, but practical, farming skills to capable young people of modest means from rural areas.

5. Environmental claims also became an integral part of the anti-green revolution opposition movement at roughly the same time (see Dahlberg, 1979). In contrast to Hightowerism, however, environmental claims-making bolstered the anti-green revolution movement. It survives largely intact to this day in terms of its focus on social justice and altering public sector research priorities. As will be stressed shortly, activism toward agricultural research in the US has bifurcated into two largely separate strands, has largely shed social justice appeals with respect to small and family farmers, and has deemphasized the contestation of public agricultural research.

6. Hadwiger (1982) used the expression "ex/al" movement (externalities/alternatives) to describe what in this paper I refer to as Hightowerism. Note, though, that by the early 1980s Hightowerism had witnessed an expansion of its scope and discourses to include not only the socioeconomic costs of land-grant technology, but also the environmental consequences.

7. I am not aware of the exact date that the Agribusiness Accountability Project folded, but it was probably an organization in decline well before 1980. Note that there are two heirs to the "agribusiness accountability" symbol and descendents of Hightowerism: Al Kreb's Corporate Accountability Research Project (http://home. earthlink.net/avkrebs/CARP/) and Agribusiness Accountability Initiative of Center of Concern (CoC), a Catholicrelated corporate activism NGO (http://www.coc.org/focus/ private/aai.html). Krebs was at one time a staffer of the Agribusiness Accountability Project (and later was a staffer at Rural America, Inc.). While CARP and CoC continue to bear the mantle of Hightowerism, this omnibus, social-justice-driven movement aimed at mobilizing a family-farmer clientele to contest public agricultural research priorities has largely ceased to exist. The collapse of the Agribusiness Accountability Project and Rural America during the 1980s led to the formation of the National Family Farm Coalition (NFFC) in 1986. Also, during the late 1980s and the 1990s the National Farmers Union (NFU) greatly increased its activist profile. The NFFC and NFU have been the main heirs of the Agribusiness Accountability Project's and Rural America's social-justice activism, but both organizations place little emphasis on affecting public agricultural research priorities. Both the NFFC and NFU play minor roles in the anti-genetic engineering movement (see Mooney and Majka, 1995: Chapter 4, for an overview of agricultural social protest in the 1980s).

8. Interestingly, the increased availability of funds for molecular biology was mainly with regard to funding from NIH and NSF. In most of the top-level land-grant colleges of agriculture today, NIH is the largest funder of research.

9. The most comprehensive source on the anti-genetic engineering movement is Schurman and Kelso (2003). Note that over the past decade or so the anti-genetic engineering movement's efforts to influence land-grant research policymaking have been limited to two areas: contesting the 1999 Novartis-University of California, Berkeley research agreement, and criticism of universities' roles in promoting patent and other intellectual property restrictions on university knowledge.

10. When I mention land-grant college "inertia," the referent is activist groups' perceptions of responsiveness to a more progressive agenda. In a broader sense, of course, it can be said that the land-grant system was extraordinarily dynamic in how it underwent molecularization, increasingly emphasized basic research at the expense of applied research, deemphasized Cooperative Extension as its major modality for transferring new knowledge and technology to private actors, and established a substantially new private system of technology transfer built around aggressive patent "discovery," exclusive licensing of patented inventions, receipt of royalty income, and establishment of material transfer agreements.

11. There are three main sources of applied research funding in the land-grant system. Historically, the most important source was that of Hatch (or "formula") funds, the type of funds that were first authorized by the Hatch Act of 1887 . The second major source - and the only one that has held its own over the past two decades - is that of agricultural commodity groups (organizations of farmers who produce a particular commodity such as wheat, corn, soybeans, pork, or beef). A third - and another declining - source is that of agribusiness corporations that provide contracts for land-grant product testing and product development.

\section{References}

Belden, J. (1986). Dirt Rich, Dirt Poor. New York: Routledge and Keegan Paul.

Busch, L., W. B. Lacy, J. Burkhardt, and L. R. Lacy (1991). Plants, Power, and Profit. Oxford, UK: Basil Blackwell.

Buttel, F. H. (1993). "Ideology and agricultural technology in the late 20th century: Biotechnology as symbol and substance." Agriculture and Human Values 10: 5-15.

Buttel, F. H. (1997). "Some observations on agro-food change and the future of agricultural sustainability movements." In D. Goodman and M. Watts (eds.), Globalising Food: Agrarian Questions and Global Restructuring (pp. 344-365). London, UK: Routledge. 
Buttel, F. H. and L. Busch (1988). "The public agricultural research system at the crossroads." Agricultural History 62(Spring) 303-324.

Cleaver, H. (1972). "The contradictions of the Green Revolution." American Economic Review 62: 177-186.

Dahlberg, K. A. (1979). Beyond the Green Revolution. New York: Plenum.

Danbom, D. (1979). The Resisted Revolution. Ames, Iowa: Iowa State University Press.

Danbom, D. B. (1986). "Publicly sponsored agricultural research in the United States from an historical perspective." In K. A. Dahlberg (ed.), New Directions for Agriculture and Agricultural Research (pp. 142-162). Totowa, New Jersey: Rowman and Allanheld.

Goodman, D. and M. Redclift (1991). Refashioning Nature. London,, UK: Routledge.

Hadwiger, D. F. (1982). The Politics of Agricultural Research. Lincoln, Nebraska: University of Nebraska Press.

Hadwiger, D. F. and W. P. Browne (eds.) (1978). The New Politics of Food. Lexington, Massachusetts: Lexington Books.

Hightower, J. (1973). Hard Tomatoes, Hard Times. Cambridge, Massachusetts: Schenckman.

Jenkins, J. W. (1991). A Centennial History: A History of the College of Agricultural and Life Sciences at the University of Wisconsin-Madison. Madison, Wisconsin: College of Agricultural and Life Sciences, University of Wisconsin.

Kloppenburg, J. Jr. and F. H. Buttel (1987). "Two blades of grass: The contradictions of agricultural research as state intervention." Research in Political Sociology 3: 111-135.

Krimsky, S. and R. Wrubel (1996). Agricultural Biotechnology and the Environment. Urbana, Illinois: University of Illinois Press.
Marcus, A. I. (1986). " From state chemistry to state science: The transformation of the idea of the agricultural experiment station, 1875-1887." In L. Busch, and W. B. Lacy (eds.), The Agricultural Scientific Enterprise (pp. 3-12). Boulder, Colorado: Westview Press.

Mooney, P. H. and T. J. Majka (1995). Farmers' and Farm Workers' Movements: Social Protest in American Agriculture. New York: Twayne.

National Academy of Sciences, National Research Council (NRC) (1972). Relevant Agricultural Research for the Seventies. Proceedings of the 20th Annual Meeting of the Agricultural Research Institute, October 12-13, 1971, St. Louis Missouri. Washington DC: NRC.

Perkins, J. H. (1997). Geopolitics and the Green Revolution. New York: Oxford University Press.

Rissler, J. and M. Mellon (1996). The Ecological Risks of Genetically Engineered Crops. Cambridge, Massachusetts: MIT Press.

Ruttan, V. W. (1980). Agricultural Research and the Future of American Agriculture. St. Paul, Minnesota: Department of Agricultural and Applied Economics, University of Minnesota, Institute of Agriculture, Forestry, and Home Economics. Schurman, R. and D. T. Kelso (eds.) (2003). Engineering Trouble: Biotechnology and Its Discontents. Berkeley, California: University of California Press.

Thompson, P. B. (2003). "The environmental ethics case for crop biotechnology: Putting science back into environmental practice." In A. Light and A. De-Shalit (eds.), Moral and Political Reasoning in Environmental Practice (pp. 187217). Cambridge, Massachusetts: MIT Press. 